\title{
A Study onTrees-basedRemedies used for the treatment of maternal illnesses in Madaroumfa Village of Maradi Department of Niger Republic
}

\author{
M.N. Danjuma ${ }^{1 *}$ and B. Maiwada ${ }^{2}$ \\ ${ }^{I}$ Department of Geography, Isa Kaita College of Education, Dutsin-ma, Katsina, Nigeria \\ ${ }^{2}$ Department of Geography, Isa Kaita College of Education, Dutsin-ma, Katsina, Nigeria
}

Correspondence: nurdkat81@gmail.com

\begin{abstract}
Tree-based remedies are historically integral parts of societies' medical regimes in many parts of the World.This is as a result of their efficacieswhich are widely acknowledged by users in all parts of developing world where folks medicine is relevant. The aim of this study is to examine the efficacy of tree remedies for the treatment of maternal illnesses in Madaroumfa village. The study is a survey research in which a total of 59 respondents were drawn from the population of 175 individualsof vegetation user groups using systematic sampling technique. Using the technique, every $3^{\text {rd }}$ order individual of a user group (farmers, herbalists, wood carvers, blacksmiths and pastoralists) is selected as a respondent. These groupswere however identified during reconnaissance. The respondents were later interviewed using 12 semi-structured questions in a group interview schedule. The study revealed that out of 53 inventoried trees of the area; about 15 are used for medicinal applications. The result further shows that there are about 10 illnesses (treated with 15 trees) which are prevalent among women in Madaroumfa. Herbal practitioners of the area used these trees or parts to prepare remedies to treat ill women at homes as well as in specialised centres. From these results, it was concluded that all respondents refer all medical cases to herbal practitioners even if they seek health from alternative sources such as hospital and clinics. The study further recommended that activities of herbal practitioners should be looked into closely because they are unstoppable and have relevance to health care of the people of the area.
\end{abstract}

Key Words: Trees-basedremedies, maternal illnesses, herbal practitioners, Madaroumfa

\section{Introduction}

Traditional medicinal practiceslikethe Arabic Unani, the Indian Ayurveda (Samal, 2013), the Chinese traditional medicine (Choi, 2009) and folks medicine of Afro-American(Taylor, 1997) which uses trees have long histories both as health care providersand healing centres in communities World over.This is whyfor generations trees-based remedies have been widely acknowledged as principal source of traditional healing regime.In recent years, the interest in traditional medicine (also known as folks medicine) of different cultures has increased significantly due to the fact that many prescription drugs Worldwide have originated from the tropical flora (Nelson-Harrison et al., 2002). An earlier estimate of the World Health Organisation (WHO) in 1991showed that the usage of traditional medicine in developing countries is $80 \%$ while Fratkin (1996) maintained that although Western medicine has become widespread in developing countries, many rural communities are still heavily dependent on plant-based therapies for their primary healthcare. With a strong root in Africa, statistics show that 75 to 90 per cent of local communities in Kenya rely on ethno-medicine as the dominant health care system (Sindigaet al., 1995). Traditional medicine is central to the provision of healthcare and supports to well over $60 \%$ of the rural population in Tanzania (Kisangau et al., 2007). In Uganda about 70 $80 \%$ of the population still rely on traditional healers for day-to-day health care while in some rural areas the percentage is around ninety compared to $80 \%$ reported World-wide (Kakudidi et al., 2000).Although modern medicine was widely sought by a large proportion of the community, traditional perceptions of health issues and diseases, and their management using herbal medicine remain popular even among those who periodically seek Western-based medication. In most cases, illnesses were first treated using local herbs but if there was no improvement or the patient was in critical condition, Western medication was sought in the few locally available clinics and dispensaries. Initial home treatment of sick people is quite common among the African people (Brown, 1995). This high dependence on traditional plant remedies in most African populations is partly attributed to traditional beliefs and lack of reliable modern health care (Sindigaet al,. 1995).

Maternal illnesses have become World pressing issue and complications resulting from pregnancy ailments remain high even with measures taken globally. Thus treating maternal illnesses is a functional aspect of traditional herbal system because of the importance attached to progeny in Africa. According to the United Nations Children's Fund (UNICEF), an average of 1,530 women falls pregnant every day in Mali. Of these, 230 
experience complications during pregnancy, while 20 die. About 100 of the children they deliver also die. In addition, several women develop serious postnatal conditions such as fistulas and descended uteruses (Grieco and Turner, 2005). Trichomonasvaginalisis a prevalent urogenital infective agent in both developed and in developing countries (Muelas-Serrano et al., 2000). Trichomoniasis is a sexually transmitted disease and the most common cause of vaginal discharge (Heine and McGregor, 1993).

A maceration of the bark of Cassinetransvaalensisand Piper capenseis drunk to treat venereal diseases (Arnold and Gulumian, 1984). Powdered bark of the latter isalso mixed with petroleum jelly and applied to wounds and the vaginato cure vaginal discharge (Arnold and Gulumian, 1984). Traditional healers in Venda prescribe infusions, decoctions or macerations of the roots of Securidacalongepedunculatato be taken orally as an aphrodisiac, for virility and to treat impotencyand as a contraceptive (Mabogo,1990). The roots and root-bark are reported as being used in the treatment of venereal diseases in Zimbabwe, Malawi and Mozambique(Neuwinger, 1996a). In these countries, the peeled root or root pulp is widely used as a suicide poison by inserting it in the vagina (Watt and Breyer-Brandwijk, 1962). Cassia species have high repute as drugs and poisons. For instance, Cassiasieberianais usedto treat impotency and kidney diseases in Mali (Neuwinger, 1996b).

\section{Study Area}

The Maradi department of the southern Niger is one of the eight Regions of Niger Republic. It is located in south-centre Niger, east of the Region of Tahoua, west of Zinder, and north of Nigeria's city of Katsina. The Maradidepartment shares borderwith Nigeria's Katsina and is located between latitude $12^{\circ} 59^{\mathrm{I}} \mathrm{N}$ and $13.5^{0} \mathrm{~N}$ and longitude $7.1^{\circ} \mathrm{E}$ and $7^{0} 36^{\mathrm{I}} \mathrm{E}$. This is one of 23 most densely populated areas in West Africa because of its density of over 200 inhabitants per sq. km (Abdoul and Trémolières, 2007).

Madaroumfa village is located between latitude $13^{0} 18.222^{\mathrm{I}} \mathrm{N}$ and $13^{0} 18.223^{\mathrm{I}} \mathrm{N}$ and longitude $007^{0} 09.521^{\mathrm{I}} \mathrm{E}$ and $007^{0} 09.522^{\mathrm{I}} \mathrm{E}$. Madaroumfa remains the largest administrative sub-division of the Maradi department (now province) which has a populationof 9791 persons in 2001 census (travellingluck.com).

The climate of the study area is the 'Aw' type as determined by Koppen in which distinctive wet and dry seasons are caused by the fluctuations of the ITCZ (Inter-tropical convergence zone) or the ITD south to north (rainy season), vice versa (dry season) and meeting at a front. The peak of rainfall in such environments is always August as noted by Mortimore (2001) and the rainfall is mostly insufficient, unreliable and unpredictable (Mortimore, 1989). Temperature is more extreme in the Maradi area during the dry season reaching over $42^{\circ} \mathrm{C}$ in the day (travellingluck.com).

The distribution of rain in the Maradi department greatly influences vegetation resources of the area. The vegetation of parts of Maradi(where Madaroumfa is situated) is composed of indigenous species which grow spontaneously. The trees found include Parkiabiglobosa, Adansoniadigitata, Khayasenegalensis, Fadherbiaalbida, Tamarindusindica, and Borassusaethiopum, and exotic species Azadirachtaindica,Eucalyptus camaldulensis.

\section{Methodology}

The main data sources were the transect walk (for species inventory) and group interview administered on sample of respondents drawn from the population of vegetation user groups of the study village. The interview was guidedby checklist of ten (10) questions while the transect walk was conducted with local guides radially from the center of the village.

The population consists of 175 members of vegetation user groups of the village as at October 2011.These user groups (sampling frames) were identified during reconnaissance and atotal of five (5) user groups were recorded. These are farmers, herbalists, blacksmiths, pastoralists and wood carvers. Members of user groups were assigned numbers irrespective of gender and selected using systematic sampling technique.Using the technique, each $3^{\text {rd }}$ order consecutive individual of a user group was selected as a respondent. A total of 59 members who were selected forms up the respondents as summarized in table 1.

Table 1: Population and Sample of respondentsbased on User Groups

\begin{tabular}{|c|c|c|}
\hline \multirow{2}{*}{$\begin{array}{l}\text { User Groups } \\
\text { Farmers } 98\end{array}$} & \multirow[t]{2}{*}{ Population } & \multirow[t]{2}{*}{ Number of Respondents } \\
\hline & & \\
\hline Herbalists 23 & & \\
\hline Wood carvers & 10 & 04 \\
\hline Blacksmiths & 12 & 04 \\
\hline Pastoralists & 32 & 11 \\
\hline
\end{tabular}

Source: Author (2011) 


\section{Result and Discussions}

Prevalent Illnesses of the Area

Table 2 present a total of ten (10) most frequent illnesses that bedevil women of the area. These are obtained based on interview responses and thus are mere expressions of the respondents.

Table 2: Prevalent Maternal Illnesses ofMadaroumfa Village

\begin{tabular}{lll}
\hline Terms of Illnesses & & Symptoms \\
\hline Hausa & English & Pains in the stomach \\
Ciwonciki & Abdominal discomfort & Ache in affected areas \\
Ciwonjiki/kai & General body ache/ Headache & Pains in the breast \\
Ciwonnono & Breast ailments & Loose stool \\
Zawo & Diarrhoea & High body temperature \\
Masassara & Fever & Rise in blood pressure \\
HawanJini & High Blood pressure & Inability to give birth \\
RashinHaihuwa & Infertility & Protrusion and pains inthe anus \\
Dankanoma & Pile & $\begin{array}{l}\text { Pains in the lower abdomen } \\
\text { Ciwonmara }\end{array}$ \\
Tsanki & Post-delivery pains & $\begin{array}{l}\text { Pains, discharges and } \\
\text { rashes in the vagina }\end{array}$ \\
\hline
\end{tabular}

Source: Author (2011)

Result of table 2 showed that the symptoms are based on physical feelings as the herbal practitioners have no technic of further testing them empirically. These illnesses are diagnosed based on the explanations offered by the patients.Most of the respondents when contacted mentioned that they cannot ascertain why these diseases have become very common in the area although some may speculate that the cause of some illnesses may be spiritual. Diseases such as high blood pressure and in fertility are always difficult to handle although some practitioners have started modernising their knowledge in the area. Fever and general body ache were said to be most referred illnesses of the area. They are treated using concoction of Guierasenegalensis, an analgestic species and sometimes Azadirachtaindicarespectively. Breast sores and vaginal illnesses are frequent among child-bearing age women in the area as indicated most respondents although all age above puberty can suffer from it. Pile and diarrhoea are common to all and the former has no specific remedy.

\section{List of Medicinal Trees of the Area}

A total of 15 medicinal trees were found in Madaroumfa village out of 53 inventories trees. These trees are specifically used for the treatment of maternal illnesses in the area. This table however does not present a pharmacopoeia of the area but a list of local medicinal trees obtained from inventories and interviews with respondents in the study area.

Table 3: Trees used for the Treatment of Maternal Illnesses in the Area

\begin{tabular}{|c|c|c|}
\hline \multicolumn{2}{|l|}{ Name of MedicinalTrees } & \multirow[t]{2}{*}{ Remedy for } \\
\hline $\begin{array}{ll}\text { Botanical } & \text { Lo }\end{array}$ & Isa) & \\
\hline Acacia macrostachyta & Gardaye & General pain in the body \\
\hline Acacia nilotica & Bagaruwa & Pile \\
\hline Azadirachtaindica & Bedi & Fever, pile \\
\hline Balaniteaegyptiaca & Aduwa & Pregnancy induced constipation \\
\hline Bauhinia rufesceus & Dirga & $\begin{array}{l}\text { Pregnancy related difficulties such } \\
\text { as morning sickness and nausea }\end{array}$ \\
\hline Bosciasalicifocia & Zure & Headache \\
\hline Cassia singuena & Runhu & Post-delivery abdominal pains \\
\hline Cassia simmea & Dorawarbature & High blood pressure \\
\hline Ficuspolita & Durumi & Breast pains \\
\hline Ficusthonningii & Chediya & Fever \\
\hline Isoberlinadoka & Doka & Diarrhoea \\
\hline Maeruaangolensis & Ciciwa & Abdominal discomfort \\
\hline Proposisafricana & Kirya & Pile \\
\hline Streospermumkunthiatum & Sansame & Vaginal pus and rashes \\
\hline Tamarindusindica & Tsamiya & Pile \\
\hline
\end{tabular}

Source: Author (2011) 
Result in table 3 showed a total of 15 medicinal trees which are used for preparations of herbal remedies for specific illness in Madaroumfa village. All trees provide remedies for specific illness with the exception of Azadirachtaindicathat is used in treatment of many illnesses in the area. The efficacies of these trees for treatment are intuitively tested and thus no side effects are proven yet from the administration of these remedies. Moreover because the remedies are not empirically prepared, only the herbal specialists are consulted on how to preparation of some at home.

\section{Methods of Preparation}

Table 4 showed that there are six (6) methods through which remedies are prepared in Madaroumfa village. The methods as presented are exclusively reported from the respondents. Theyare traditionally intuitive ways of preparing remedies which are sometimes tasking and involve rigorous work.

Table 4: Methods of Preparation of Remedies

\begin{tabular}{lcl}
\hline Methods of Preparation & Mode of administration Non-Tree Ingredients(if any) \\
\hline Cooking & Oral & animal products \\
Grinding & Oral and external & animal products such as milk \\
Infusion & Oral and external & potash, animal products \\
Insertion & Insertion in anus & ointments \\
Soaking & Oral & not available \\
Smoking & Nasal & not available \\
\hline
\end{tabular}

Source: Author (2011)

The table showed that parts of trees are cooked, grounded or infused either only or with other ingredients and administered orally and externally through rubbing and insertion. Normally oral ingestions are meant for internal illnesses such as fever, diarrhoea and abdominal discomforts while insertion is for pile and vaginal discharges. Some processes requirenasal administration and therefore parts of trees are burn to produce scents. Here patients are required to inhale the scent through nose.

\section{Parts of Trees Used}

Figure 1 showed four (4) parts of trees that are used in area to prepare herbal remedies to cure and prevent maternal illnesses in the area. These are the only trees parts which use reportedare obtained even though other parts which may beare not mentioned.

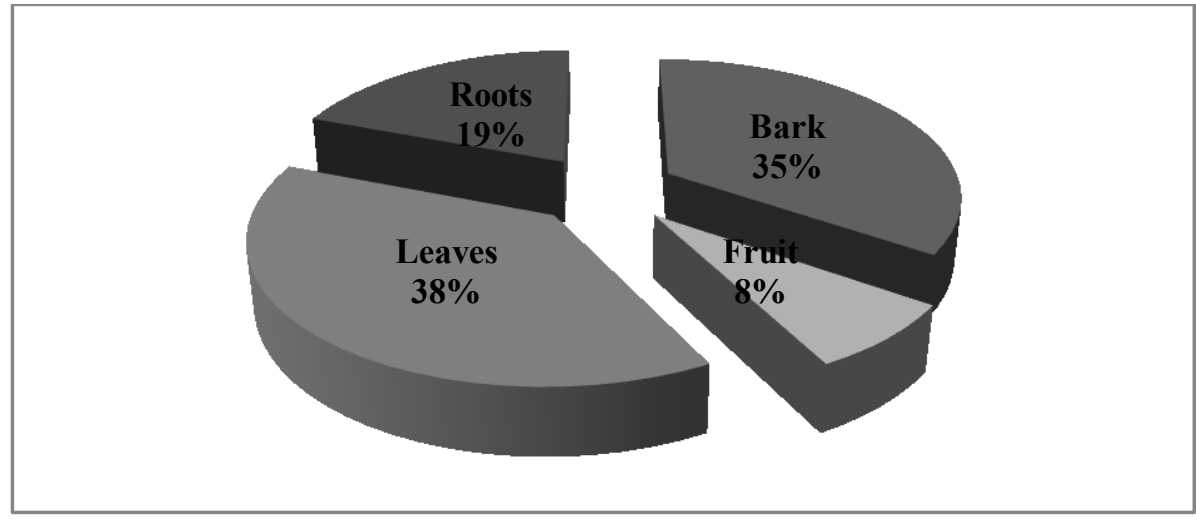

Figure 1: Parts of Trees Used for preparation of remedies in the area

Result in figure 1 revealed that leaves and barksof trees are highly used parts in the area with $38 \%$ and $35 \%$ of the scores of respondents.Most respondents noted that leaves and barks of trees are collected easily even by women and young children which may be the reason why they are used more often. Moreover these parts can be processed through all methods and stored for long without any means of preservation. The result further depict that fruits are used but less often because they are considered first as food then as medicine as mentioned most respondents. Roots are also used but because of stringent laws on trees felling and harvesting of parts in the area, the use of them are not common and substituted with other parts. 


\section{Health seeking sources of the Area}

Table 5 indicated that there are two health seeking sources of respondents in Madaroumfa village. The table depicts that preference of respondents' on health seeking sources vary significantly among user groups may be becauseof culture and satisfaction levels between sources available to them.

Table 5: Respondents' preferences between health seeking sources

\begin{tabular}{llcl}
\hline User Groups & \multicolumn{3}{l}{ Preference based on respondents choices } \\
\hline \multirow{3}{*}{ Farmers } & \multicolumn{4}{l}{ Herbal centres onlyClinics onlyBoth } & 02 \\
Pastoralists & 20 & - & 02 \\
Herbalists & 09 & - & - \\
Wood carvers & 08 & - & 01 \\
Blacksmiths & 03 & - & 02 \\
\hline Total & 02 & $\mathbf{0 2}$ & $\mathbf{1 4}$ \\
\hline Source: Author $(2011)$ & $\mathbf{4 3}$ &
\end{tabular}

Source: Author (2011)

Result in table 5confirmedthat all respondents refer medical conditions to herbal practitioners of the area even if they may seek help in clinics. It further showed that only few farmers exclusively refer to clinics for health while significant number of other user groups' members attends both herbal centres and clinics with the exception of herbalist who do not go to clinics at all. Farmers of the area are better informed of clinics as health care providers because they frequently travel to Nigerian markets for marketing of produce. This may avail them the opportunity of acquiring modern knowledge.Herbal centres of the area enjoy highest patronage by all respondents because of satisfaction with their remedies and may be because of in access to knowledge of clinics as well as culturally induced phobia of orthodox medicines.

\section{Reasons of choosing health seeking sources}

Respondents of the area invariably prefer health seeking sources from among choices available to them. A total of four (4) reasonswere found to be behind these preferential choices as indicated in figure 2. These reasons are strictly obtained from the key informants during reconnaissance while the percentage reflects the views of the respondents.

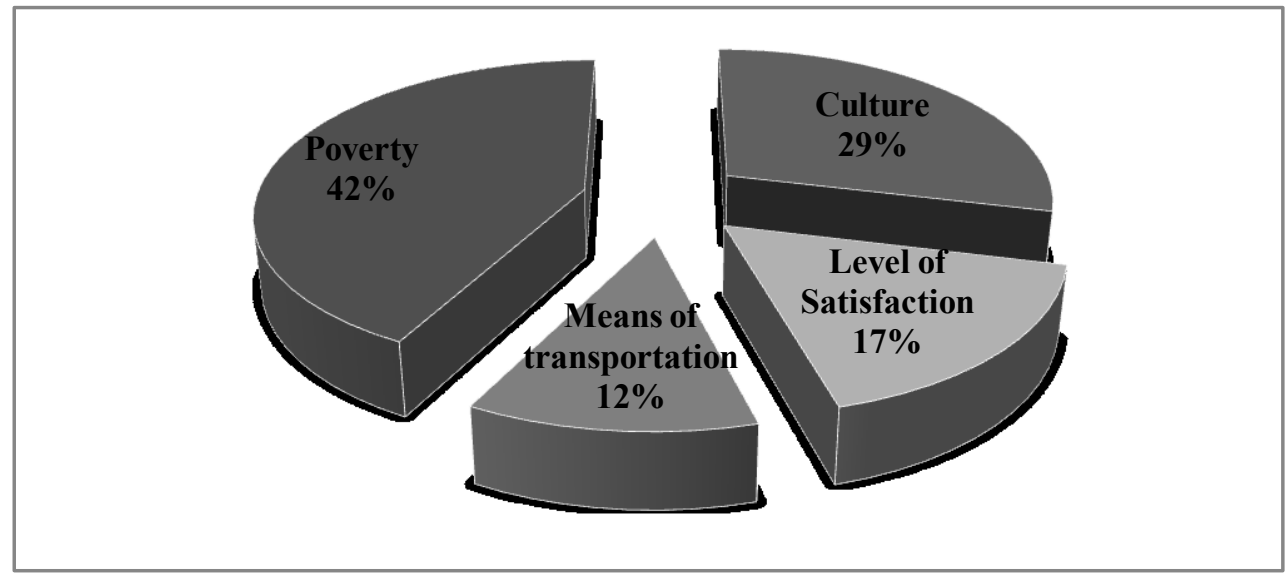

Figure 2: Reasons of choosing health seeking sourcesof the Respondents

Result in figure 2 showed that poverty which translates into the cost of going to clinics and buying drugs is the major reason why respondents ignore clinic for medical help. Most respondents when contacted mentioned that even though one clinic is available in the area, they not be able to bear cost especially of complicated illnesses which may require admission. Respondents will easily refer medical cases to herbal practitioners even if they are penny less because of rural obligation of helping one another. Culture in terms of old phobia and anecdotal reports of clinic as areas where people die easily and/or are converted affect clinic and favours herbal centres in the area. Level of satisfaction is another reason that determines where to refer cases to even among herbal centres available in the area. It is mentioned that they prefer herbal remedies to orthodox because they are prepare with local ingredients which sourced by themselves. Transport play an insignificant role because herbal centres and a clinic of the area are all located in the village. Respondents indicated that it is vital only when referring emergency cases to hospitals or more renowned practitioners outside the village. 


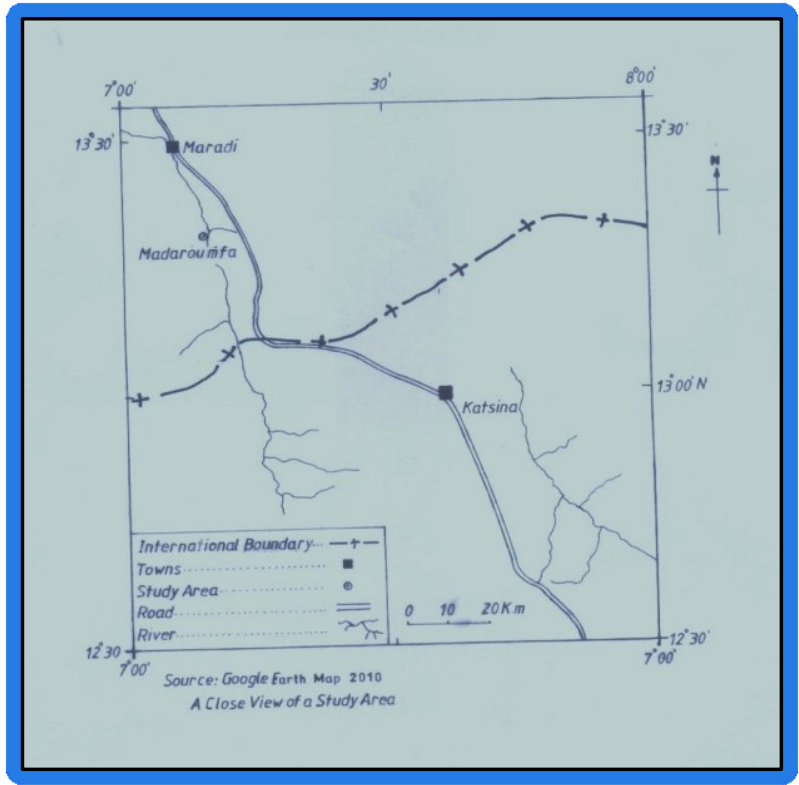

Figure 3: Map of the study Area

\section{Conclusion:}

This study revealed that the women of the area are constantly battling with diseases because they do not only refer to herbal practitioners but consult orthodox health officers were clinics are available. Tree based remedies are prepared as first line treatments at home before referring to professionals for help or when illnesses become complicated. It further showed that the various user groups contacted in the study have different reason of choosing health seeking behaviour even though cost of accessing drugs in the hospital as well as transportation are the favoured over all. The ethos of the study is that it identified ten maternal illnesses of Madaroumfa village, specific herbal remedies as well as how they are prepared through intuition. The study does not engage into any clinical trial of the efficacy of the drugs used and therefore solely depends on the knowledge obtained from the respondents. Further investigations can dwell into experimentation to prove the quality of remedies prepared for hitch free usage.

\section{Recommendation:}

It was recommended that the herbal practitioners should be integrated into health care programmes of the government and NGOs because of their relevance to health of the people of the area.

\section{References}

[1]. Abdou, M. and Trémolières, M. (2007).Cross-Border Cooperation between Niger and Nigeria: The Case of the Maradi MicroRegion. In Fredrik Söderbaum and Ian Taylor (eds). Micro-Regionalism in West Africa: Evidence from Two Case Studies (2007). NordiskaAfrikainstitutet, Uppsala, Discussion Paper 34. Printed in Sweden by ElandersGotab AB, Stockholm

[2]. Arnold, H-J. and Gulumian, M.( 1984). Pharmacopoeia of traditional medicine in Venda. J Ethnopharmacol, 12

[3]. Brown, K. (1995). Medicinal plants, indigenous medicine and conservation of biodiversity in Ghana in Intellectual Property Rights and Biodiversity Conservation. Edited by T. Swanson. Cambridge University Press, United Kingdom.

[4]. Choi, Seung-hoon (2009). World Health Organisation (WHO) Strategy and Activities in Traditional Medicine, WHO, Western Pacific Regional Office, Manila, Philippines.

[5]. Fratkin, E. (1996). Traditional medicine and concepts of healing among Samburu pastoralists of Kenya. Journal of Ethnobiology 16:63-97.

[6]. Grieco, M. and Turner, J. (2005). Maternal mortality: Africa's burden. Toolkit on Gender, transport and maternal mortality. United Kingdom

[7]. Heine, P. and McGregor, J.A. (1993) Trichomonasvaginalis: a re-emerging pathogen. ClinObstetGynecol36: 137-144

[8]. http:/travellingluck.com / Africa / Niger / Maradi / - 2441526 - Madaroumfa. Html \# local - map, retrieved on 28 / 05 / 2009.

[9]. Kakudidi, E.K.;Bukenya-Ziraba, R.;Kasenene J.(2000). The Medicinal Plants in and around Kibale National Park in Western Uganda. A Norwegian Journal of Botany, LIDIA 5 (4): 109-124.

[10]. Kisangau D.P.; Lyaruu H.V.; Hosea K.M.; Joseph, C.C. (2007). Use of traditional medicines in the management of HIV/AIDS opportunistic infections in Tanzania: a case in the Bukoba rural district. Journal of Ethnobiology and Ethnomedicine3:29.

[11]. Mabogo, D.E.N. (1990). The ethno-botany of the Vhavenda. M.Sc thesis, University of Pretoria, South Africa.

[12]. Mortimore, M. (1989). Adapting to Drought: Farmers, Famines and Desertification in West Africa, Cambridge University Press, Cambridge

[13]. Mortimore, M. (2001). A Profile of Rainfall Change and Variability in the Kano - Maradi Region, 1960 - 2000. Drylands Research Working Paper 25, Dry land Research, Crewkerne, UK.

[14]. Muelas-Serrano, S.; Nogal, J.J.; Martinez-Diaz, R.A.; Escario, J.A.; Martinez-Fernandez A.R.; Gomez-Barrio, A. (2000). In vitro screening of American plant extracts on Trypanosomacruziand Trichomonasvaginalis.JEthnopharmacol; $71^{\prime}$ 
[15]. Nelson-Harrison, S.T.; King, S.R.;Limbach, C.; Jackson, C.;Galiwango, A.; Kato, S.K.;Kanyerezi, B.R. (2002). Ethnobotanical research into the $21^{\text {st }}$ century. In: Iwu, M.M.;Wootton, J.C. (Eds.), Ethnomed. Drug Discov. Elsevier, Amsterdam.

[16]. Neuwinger, H.D. (1996a). African Ethnobotany. Poisons and Drugs. GmbH, Weinheim: Chapman \& Hall, Germany

[17]. Neuwinger, H.D.(1996b). African Ethnobotany. Poisons and Drugs; Chemistry, Pharmacology and Toxicology. Chapman \&Hall, London.

[18]. Samal J. (2013). What makes the ayurveda doctors suitable public health workforce?. Int J Med Sci and Public Health ; 2:919-923.

[19]. Sindiga, I.; Kanunah, M.P.; Nyaigotti-Chacha, C. \&Mwangola, E.S. (1995). The future of traditional medicine in Africa. Traditional Medicine in Africa. East African Educational Publishers Ltd., Nairobi, Kenya.

[20]. Taylor, S.D.; Boyd, E.D.; Shimp, L.A. (1997). Use of Home remedies by African Americans. Unpublished Manuscript, University of Michigan, College of Pharmacy, Ann Arbor

[21]. Watt, J.M.; Breyer-Brandwijk, M.G. (1962).The Medicinal and Poisonous Plants of Southern and Eastern Africa, 2nd ed. Livingstone, London.

[22]. World Health Organisation (WHO) (1991).Guidelines for the Assessment of Herbal Remedies. Traditional Medicine Programme of the World Health Organisation, Geneva. 